\title{
Having fun playing God
}

Fiji lawyer Richard Naidu filed a personal judicial review action against Fiji Islands Minister for Telecommunication Ratu Inoke Kubuabola's decision to direct Fiji TV to broadcast the Hongkong Sevens tournament live on Fiji One. The case for why the minister's direction set a dangerous precedent.

\section{By RICHARD NAIDU}

IN THE Fiji Sunday Times of 21 March 1998, Jo Turaganivalu (the senior civil servant with responsibility for television and telecommunications regulation) wrote an article headed REGULATOR'S STAND NEEDS TO BE UNDERSTOOD. It was an unfortunate heading. Considering myself a person of normal intelligence, I could barely understand a word of it.

I read in the article the justification of the Millennium and Hongkong Sevens decisions. I couldn't understand that either.

In December 1997, the Television Minister issued an order prohibiting Fiji TV from broadcasting the Millennium series which, as far as I know, was a scifi programme with some sex and violence. I found this edict disquieting, but did not have much to say. I had never seen the programme; some of the Fiji TV's programming choices are in my view questionable; and the minister at least had the legal power to do what he did, although he ought not to be encouraged to use it.

The Hongkong Sevens decision, however, is different.

$\square$ It is a direction to broadcast, not a direction to withdraw; it is saying "you must broadcast this". Not only is that dangerous, but on my reading of the law the minister has no power to do it.

$\square$ It has no moral justification at all.

The minister has given no thought to the quite serious impact an immature decision will have on Fiji TV's commercial arrangements.

48 PACIFIC JOURNALISM REVIEW 5:1 1999 
My legal challenge to the minister's decision is public knowledge and I do not intend to go into the merits of this, except to suggest that I do not think the minister, as television regulator, understands his role at all.

First, on my reading of the Television Decree, while the minister has the power to prohibit certain broadcasts "in the interest of the general public", he has no power to tell Fiji TV what to broadcast unless on the occurence of a public emergency. One can understand that the unavailability of live coverage of the Hongkong Sevens may to some minds, fall into the emergency category, but if the minister thought so, he has not said it.

Second, the role of the regulator is not to "play God". The regulator is required to act within the law and to use those powers he has in a reasonable way. His powers in this area should be used with restraint, not to impose his personal moral view on us; not to win arguments which he would lose on logic; not to produce the outcomes he wants just because he wants them.

Turaganivalu says of the Millennium and Sevens decisions: "Perhaps what is important is the outcome."

Wrong. What is important is that the minister plays the game by the rules that everybody started with and that he gains everybody's confidence by making decisions that everybody understands.

Is the minister playing by the rules ?

A lot was said last week about regulating monopolies. The implication is that monopolies (presumably television monopolies because there are no print and radio monopolies) are bad and must be dealt with. In 1994, Government the same minister, in fact - gave Fiji TV a 12-year exclusive licence.

The Government thus created the monopoly; Government negotiated the terms of Fiji TV's licence (Government did not require the live broadcasting of the Hong Kong Sevens); Government patted itself on the back because it had got the private sector to invest in something the Government had neither the money nor the skills to offer to the public.

Alas, when you abdicate your functions to private enterprise, you find that, because private enterprise is more responsive to consumers and more profitdriven (not always a good thing with television), you do not always get what, as minister, you expected private enterprise to deliver, (including the Sevens on free-to-air).

Things change. Rugby is going professional. Rugby has to pay its players somehow (they don't all get Government guarantees) and selling pay TV is how it does it. Perhaps the minister did not think of this in 1994, when he granted the 


\section{RICHARD NAIDU}

licence. He is stuck with that problem.

But no, he says. I have the power to play God. I will use that power to make things look the way I expected them to look four years ago. And while I am about it (the minister says), the television monopoly I have got doesn't look like the sort of television monopoly I thought it would be four years ago. So I'll play God there as well and break the monopoly. I will just do what it takes to make a television station in my image.

And I will hope that each decision I take will be one of those decisions to which Fiji TV will bend, because Fiji TV will decide that this is time to play politics and play along ("under protest", naturally).

It is, as a matter of principle, outrageous for a minister to dictate to a media organisation what programmes that organisation will offer to the public.

No amount of bureaucracy-speak can hide the fact that this is a grubby political pitch for popularity, at the expense of media independence and, ultimately freedom of expression.

Typical libertarian hype over nothing, I hear you say: Calm down. Just this once, just one little rugby tournament.

But the temptation to use the heavy hand of "regulation" (which has another name - "censorship") becomes' greater as you go along.

It can be fun playing God. And if people get the Sevens live, in the public interest, surely others should get the soccer World Cup finals? Isn't that in the public interest, too? Anyone for cricket?

What else is on offer? What about say, a four-hour prime ministerial stateof-the-nation speech in 1999 (coincidentally timed one week before the election campaign opens)? Might not that be in the public interest too?

And will the last possibility wake the opposition parties from their collective slumber? Where are the howls of protest from that quarter?

Nothing. The votes, it seems, are with the Sevens.

I am not against regulation. Regulators have a role, and they are needed because Fiji TV's programming choices need to be monitored in the public interest. The regulator's role is to set transparent and fair rules. within the law, and stick to them.

Pick the players the country needs (they need licences after all), speak softly (after all you carry a big stick); persuade rather than dictate, and be prepared to be persuaded.

It's a bit like the formula for success of the great old movie director they honoured at the recent Academy Awards, who said something like this: "Get 50 PACIFIC JOURNALISM REVIEW 5:1 1999 
FIJI TV

yourself a good script. Get yourself a good cast. Put them together. Then get the hell out of the way."

Richard Naidu is a media lawyer and a former journalist. Although he acts for Fiji Times Ltd, he filed this legal action as a private citizen. The minister's decision was implemented when Fiji TV indicated it would comply. The legal action is now in the Fiji Court of Appeal on a preliminary point. The Hongkong Sevens tournament was shown live on Fiji One in 1998 and again in 1999. This article was originally published as "Having fun playing God" in the Fiji Times of 29 March 1998.

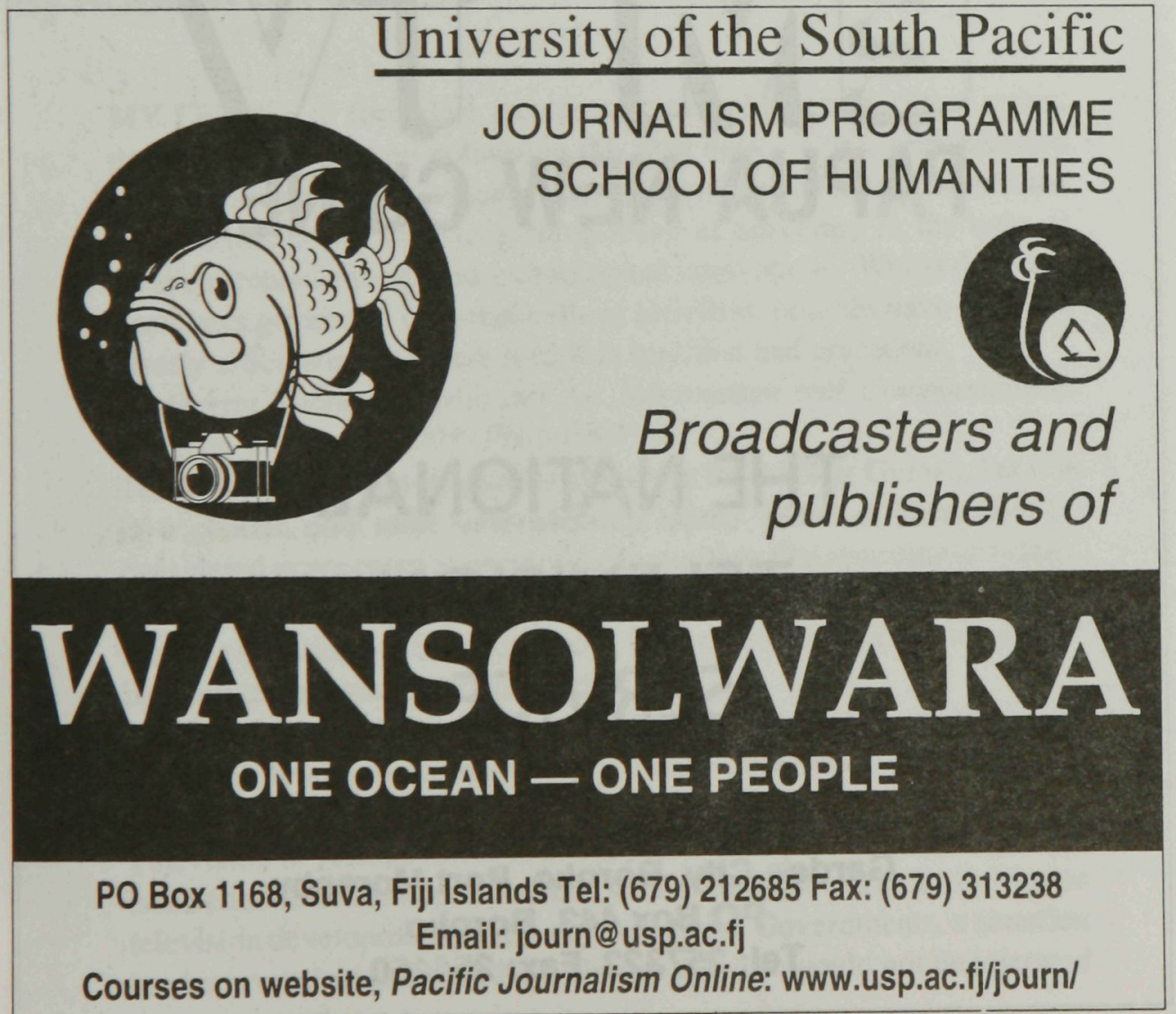

